\title{
Hepatitis B Surface Antigen Seroprevalence of Turkish and Foreign Patients of Reproductive Age in 2014-2017
}

\section{Üreme Çağındaki Türk ve Yabancı Uyruklu Kadın Hastalarda 2014-2017 Yıllarındaki HBs Antijen Seroprevalansı}

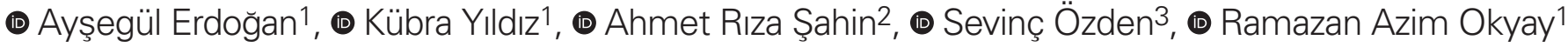 \\ ${ }^{1}$ Kahramanmaraş Sütçü Imam University Faculty of Medicine, Department of Public Health, Kahramanmaraş, Turkey \\ 2Kahramanmaraș Sütçü Imam University Faculty of Medicine, Department of Infectious Diseases and Clinical Microbiology, Kahramanmaraș, Turkey \\ ${ }^{3}$ Kuşadası State Hospital, Clinic of Microbiology, Aydın, Turkey
}

\begin{abstract}
Objectives: Cross-country migration may affect the prevalence of hepatitis B virus (HBV). Due to the recent war in Syria, there has been a serious exodus towards Turkey. In this study, it was aimed to investigate the hepatitis B surface antigen (HBsAg) seroprevalence among women of reproductive age of foreign origin, both Turkish and mostly Syrian immigrants.

Materials and Methods: In this study, we retrospectively evaluated the HBsAg results of 55.057 patients, mostly pregnant and aged between 15 and 49 years who presented to a Maternity and Children Hospital between January $1^{\text {st }}, 2014$, and December 31 ${ }^{\text {st }}, 2017$. Results: In both Turkish and foreign origin patients, the seropositivity of HBsAg was found to be $1.1 \%$. However, in women over 40 , those of foreign origin were higher than Turkish women.

Conclusion: Our region is low endemicity in terms of HBsAg seroprevalence in women of reproductive age. In addition, women of foreign origin are not different than women of Turkish origin in this respect. However, in future years, the migrant population may be disadvantaged if they do not receive adequate health care.

Keywords: HBsAg seroprevalence, Syrian refugees, reproductive age, women
\end{abstract}

ÖZ

Amaç: Ülkeler arası göç hepatit B virüs (HBV) yaygınlığını etkileyebilmektedir. Suriye'de son yıllarda yaşanan savaş nedeniyle, Türkiye'ye doğru ciddi bir göç yaşanmaktadır. Bu çalıșmada, hem Türk, hem de çoğunluğu Suriyeli göçmenlerden oluşan yabancı kökenli üreme çağındaki kadınlarda hepatit B yüzey antijeni (HBsAg) seroprevalansının araştırılması amaçlanmıştır.

Gereç ve Yöntemler: Bu çalışmada, 1 Ocak 2014 ve 31 Aralık 2017 tarihleri arasında bir kadın doğum ve çocuk hastanesi'ne başvuran, çoğunluğu hamile olan, ve yaşları 15 ile 49 yaş aralığında bulunan 55,057 hastanın HBsAg sonuçları retrospektif olarak değerlendirildi. Bulgular: Hem Türk hem de yabancı kökenli hastalarda HBsAg seropozitivitesi \%1,1 olarak tespit edildi.Ancak 40 yaş üstü kadınlarda, yabancı kökenli olanların Türk kadınlarına göre daha yüksek olduğu görüldü.

Sonuç: Bölgemiz, üreme çağındaki kadınlarda HBsAg seroprevalansı açısından düşük endemisitededir. Ayrıca, yabancı kökenli kadınlar bu açıdan Türk kökenli kadınlardan farklı değildir. Bununla birlikte, gelecek yıllarda göçmen nüfusu yeterli sağlık hizmeti almazlarsa dezavantajılı durumda olabilir.

Anahtar Kelimeler: HBsAg seroprevalansı, Suriyeli göçmenler, üreme çağı, kadınlar

Erdoğan A, Yıldız K, Şahin AR, Özden S, Okyay RA. Hepatitis B Surface Antigen Seroprevalence of Turkish and Foreign Patients of Reproductive Age in $2014-2017$. Viral Hepat J. 2020;26:5-8.

Address for Correspondence: Kübra Yıldız MD, Kahramanmaraş Sütçü Imam University Faculty of Medicine, Department of Public Health, Kahramanmaraş, Turkey E-mail: kubratosunoglu25@gmail.com ORCID ID: orcid.org/0000-0002-9094-6048 Received: 06.10.2019 Accepted: 13.12.2019

${ }^{\circ}$ Copyright 2020 by Viral Hepatitis Society / Viral Hepatitis Journal published by Galenos Publishing House. 


\section{Introduction}

Hepatitis B virus (HBV) infection is still an important public health problem in the world. It is estimated that approximately two billion people across the world face HBV and 257 million people are chronic HBV carriers $(1,2)$. HBV is transmitted through contact with skin and mucous membranes of infected blood and body fluids. Vertical transmission of HBV infection from the mother to the newborn is commonplace in areas with high endemicity, whereas in areas with middle endemicity, sexual transition is predominant (2). In the technical report of the European Centre for Disease Prevention and Control (ECDC) in 2010, Turkey was classed as a middle endemic region in terms of the prevalence of hepatitis B, and Hepatitis B Surface Antigen ( $\mathrm{HBs} A g$ ) seropositivity was reported to be approximately $5.2 \%$ (3). Although the risk of acute $\mathrm{HBV}$ infection is independent of age, the risk of chronicity of HBV infection is inversely proportional to the age at which the infection is transferred. The $90 \%$ rate of chronicity of HBV infection in the newborn decreases to $5 \%$ in adulthood $(2,4)$.

Hepatitis $B$ vaccination is the most effective way to protect against HBV infection and complications (5). Turkey added HBV vaccination to the routine childhood immunization program in 1998 $(6,7)$. In addition, it was recommended that HBsAg screening should be performed for pregnant women during the first follow-up in the Prenatal Care Management Guidelines, and HBV vaccination is recommended for pregnant women with negative HBsAg and anti HBs during or after pregnancy (8).

In order to reduce the global prevalence, governments should be determined in screening and preventive measures, the awareness of individuals should be raised, and access of carriers to health services should be enabled. Assuming that approximately onequarter of the world's population is women of reproductive age, it is possible for 65 million women to infect their babies with HBV (1). Although horizontal transmission is more frequent in Turkey, vertical transmission from mother to baby is also important $(9,10)$.

HBsAg seropositivity among pregnant women was reported to be between $1.2 \%$ and $9.3 \%$ in Turkey over the last two decades (11). However, migration between countries may also affect the prevalence of HBV (1). Due to the war in Syria in recent years, significant immigration has occurred toward Turkey from this region (12).

In this study, we aimed to investigate the HBsAg seroprevalence among women of reproductive age of Turkish and foreign origin, the latterlargely comprising Syrian refugees.

\section{Materials and Methods}

\section{Study setting}

Kahramanmaraş is a city located in the Eastern Mediterranean Region of Turkey, with a population of 1.127.623. The population of women aged $15-49$ years in the province of Kahramanmaraş is 283.949 (13). According to the Migration Report of the Republic of Turkey Ministry of Interior Directorate General of Migration Management, 86.964 Syrians were registered under temporary protection in Kahramanmaraş in 2016. There are also temporary shelter centers for Syrian refugees to Turkey in Kahramanmaraş and 17.968 Syrians reside in these shelters, receiving health services under the management of the Republic of Turkey Ministry of Health (12).

\section{Ethical considerations}

The study protocol was approved by Kahramanmaraș Sütçü Imam University Clinical Research Ethics committe (approval number: 02, date: 06.02.2019). Informed consent wasn't obtained.

\section{Study type and participants}

This study is planned in a descriptive design. In this study, the HBsAg results of 55.057 patients, the majority of whom were pregnant, aged between 15 and 49 years (reproductive period) who presented to a Maternity and Children Hospital between January $1^{\text {st }}, 2014$, and December $31^{\text {st }}, 2017$, were assessed. In the same year, repeated data of participants with multiple serum $\mathrm{HBsAg}$ concentrations were excluded. Following the removal of duplicate cases, the HBsAg results of 54.201 women were evaluated, retrospectively.

\section{Measurement of seropositivity}

HBsAg and Hepatitis B surface antigen antibody (anti-HBs) seropositivity rates were determined using ELISA. The values of the anti-HBs of $10 \mathrm{IU} / \mathrm{mL}$ and the HBsAg concentration of $1 \mathrm{IU} / \mathrm{mL}$ were considered to be positive.

\section{Statistical Analysis}

The independent variables of the study were the age and nationality of the patients. Descriptive statistics are expressed as number, mean, standard deviation, and percentage. The chi-square test and Spearman's Rho test were used for statistical analyses and $p<0.05$ was accepted as the level of statistical significance. Statistical analyses were performed using the SPSS 15.0 package program.

\section{Results}

Of the 54.201 patients, 42.679 (78.7\%) were women of Turkish origin and $11.522(21.3 \%)$ were of foreign origin. Of the foreign women, 11.361 (98.6\%) were Syrian and the rest were women from other countries. The mean age of all women was $26.64 \pm 6.64$ years. The mean age of the Turkish patients was $27.15 \pm 6.61$ years and the mean age of the foreign women was $24.77 \pm 6.41$ years.

The number of hospital admissions of female patients of Turkish and foreign origin according to years of admission is presented in Table 1.

HBsAg seroprevalence was determined as $1.1 \%$ for all patients. HBsAg seropositivity was found as $1.1 \%$ both in Turkish patients and foreign patients. HBsAg seroprevalence in women of Turkish origin was determined as $0.7 \%, 0.8 \%, 1.0 \%, 1.5 \% 1.5 \%$, $2.1 \%$, and $3.0 \%$ in the 15-19, 20-24, 25-29, 30-34, 35-39, 40-44, and $45-49$ age groups, respectively. In foreign women, it was $0.3 \%$, $0.6 \%, 1.8 \%, 1.4 \%, 2.0 \%, 4.3 \%$, and $4.7 \%$ in the abovementioned age groups. In both Turkish and foreign patients, the 15-19 years age group had the lowest seroprevalence rates, and the 45-49 years age group had the highest positivity (Table 2).

HBsAg seropositivity showed a significant increase with age. In the correlation analysis, there was a moderate relationship between age and HBsAg seropositivity at a significance level of $\mathrm{p}<0.01$ (rho: 0.43). HBsAg seropositivity rates were not different between Turkish women and those of foreign origin in total, but for those aged 40 years or above, it was found to be higher in 
women with foreign origin than in Turkish women $(p=0.048)$. This is demonstrated in Figure 1.

\section{Discussion}

The ECDC report revealed that the highest endemicity ( $\geq 8 \%)$ for HBV was observed in South Asia, China, Indonesia, Nigeria, and Sub-Saharan Africa throughout the world. In the same report, Europe and the Middle East, in which Turkey is also located, were noted as mid-endemic (2-7\%) (3). HBsAg seropositivity in women varies according to geographic region and ethnic groups (14).

In order to prevent vertical transmission, it is important to evaluate HBsAg seroprevalence in pregnant and reproductive age women (15). In this study, the HBsAg seroprevalence was found as $1.1 \%$ among women aged $15-49$ years, who mostly comprised pregnant women. This ratio is consistent with the country results in low endemic regions (16).

The HBsAg seroprevalence determined in this study is consistent with other studies conducted on women of reproductive age in different regions of Turkey. In a retrospective study of pregnant women between 1995 and 2015, HBsAg seroprevalence was found to be $1.5 \%$ in 7605 pregnant women and HBsAg decreased from $2.6 \%$ to $0.8 \%$ over a 20 -year period (17). In a study conducted in Istanbul, Turkey's most populous city, HBsAg seropositivity in pregnant women between 2008 and 2013 was determined as $1.2 \%$ (18). In another study conducted in pregnant women in Izmir in 2010-2011, the prevalence of HBsAg was found as $1.14 \%$ (19).

The CDC accept migrants as special groups in HBV epidemiology (20). More than 4 million refugees have migrated to Turkey during the civil war in Syria (12). In this study, the HBsAg seroprevalence in Syrian migrant women, who accounted for approximately one- fifth of the patients, was found as $1.1 \%$, which is similar to Turkish women. In another study conducted in Turkish and Syrian pregnant women in 2015, the total HBsAg seropositivity was found as $1.4 \%$, while this rate was $1.8 \%$ in Turkish pregnant women and $1.1 \%$ in Syrian pregnant women (21). In a study of pregnant women in Damascus, Syria, HBsAg seropositivity was found as $0.75 \%$ (22). HBsAg seropositivity in women undergoing premarital screening in Syria was found as $1.49 \%$ in 2011 and $0.68 \%$ in 2014 (23).

$\mathrm{HBV}$ vaccine was added to the national vaccination program in 1998 in Turkey. Additionally, a massive catch-up program was applied in middle and high school period, to those who were born after 1991. Thus, all people born after 1991 may practically be considered as vaccinated in terms of HBV (6). In our study, those who were considered to be vaccinated corresponded to the 15-19 and 20-24-year age groups. The seroprevalence of HBsAg in these two groups was $0.7 \%$ and $0.8 \%$. For foreign women, the seroprevalence of $\mathrm{HBsAg}$ was found as $0.3 \%$ and $0.6 \%$ in the

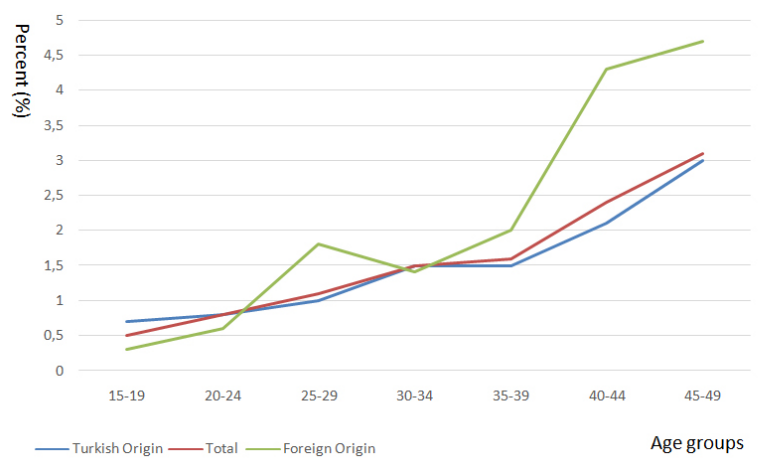

Figure 1. Hepatitis B surface antigen seropositivity by age groups

\begin{tabular}{|c|c|c|c|c|}
\hline \multirow[b]{2}{*}{ Year of admission } & \multicolumn{2}{|c|}{ Turkish origin } & \multicolumn{2}{|c|}{ Foreign origin } \\
\hline & Number & $\%$ & Number & $\%$ \\
\hline 2015 & 10.903 & 25.5 & 2572 & 22.3 \\
\hline 2016 & 10.502 & 24.6 & 3022 & 26.2 \\
\hline
\end{tabular}

Table 2. Hepatitis B surface antigen seropositivity rates according to age groups

\begin{tabular}{|l|l|l|l|l|}
\hline & \multicolumn{2}{|l|}{ HBsAg (+) Turkish origin } & \multicolumn{1}{l|}{ HBsAg (+) Foreign Origin } \\
\hline Age groups (years) & Number & $\%$ & Number & $\%$ \\
\hline $15-19$ & 34 & 0.7 & 7 & 0.3 \\
\hline $20-24$ & 97 & 0.8 & 23 & 0.6 \\
\hline $25-29$ & 105 & 1.0 & 45 & 1.8 \\
\hline $30-34$ & 124 & 1.5 & 22 & 1.4 \\
\hline $35-39$ & 69 & 1.5 & 16 & 2.0 \\
\hline $40-44$ & 28 & 2.1 & 10 & 4.3 \\
\hline $45-49$ & 15 & 3.0 & 2 & 4.7 \\
\hline Total & 472 & 1.1 & 125 & 1.1 \\
\hline HBsAg: Hepatitis B surface antigen & & & \\
\hline
\end{tabular}


15-19 and 20-24-year age groups, which may also be considered as mostly vaccinated because massive HBV vaccination began in Syria in 1994 (22). We believe this result is due to the fact that HBV vaccination programs in Turkey and Syria were put into practice at around the same time. In addition, HBsAg seroprevalence was found to be significantly higher in foreign women aged 40 years or above than in women of Turkish origin (Figure 1). However, there isinsufficient evidence in the literature to discuss why the vaccination rates in women of foreign origin are relatively lower after the fourth decade.

In our study, a significant correlation was found between age and HBsAg seropositivity. Seroprevalence decreased as age decreased (Figure 1). The lowest seroprevalence rates were found in the 15-19-year age group in Turkish and immigrant women $10.7 \%$ and $0.3 \%$, respectively). In a study conducted on pregnant women by Furuncuoglu et al. (17), seroprevalence increased with increasing age. We believe that due to the natural flow of life, increasing age enables people to encounter more infectious agents.

\section{Conclusion}

Pregnant women make up a group that is capable of representing the reproductive age female population. Our results indicated that our region is low endemic in terms of $\mathrm{HBsAg}$ seroprevalence in women of reproductive age. Also, women of foreign origin are no different than Turkish women in this respect. However, in the upcoming years, the migrant population may be disadvantaged if they are not provided with adequate healthcare or do not receive adequate focus.

\section{Ethics}

Ethics committee approval: The study protocol was approved by Kahramanmaraş Sütçü Imam University Clinical Research Ethics Committe (approval number: 02, date: 06.02.2019).

Informed Consent: It wasn't obtained.

Peer-review: Externally peer-reviewed.

\section{Authorship Contributions}

Concept: A.E., S.Ö., Design: A.E., A.R.Ş., R.A.O., Data Collection or Processing: A.E., S.Ö., Analysis or Interpretation: A.E., K.Y., R.A.O., Literature Search: A.E., K.Y., Writing: A.E., K.Y., A.R.Ş., R.A.O.

Conflict of Interest: The authors declare no conflict of interest.

Financial Disclosure: The authors declare that this study has not received any financial support.

\section{References}

1. World Health Organization: Global Hepatitis Report 2017. Available from: URL: https://apps.who.int/iris/bitstream/han dle/10665/255016/9789241565455-eng.pdf;jsessionid= DAF7E7B6C0CEBB30BDEB0379F74C349F? sequence $=1$

2. Trépo $C$, Chan HLY, Lok A. Hepatitis B virus infection. Lancet 2014; 384: 2053-2063.

3. European Centre for Disease Prevention and Control. Hepatitis B and $\mathrm{C}$ in the $\mathrm{EU}$ neighbourhood: prevalence, burden of disease and screening policies. Stockholm: ECDC; 2010.

4. Schweitzer A, Horn J, Mikolajczyk RT, Krause G, Ott JJ. Estimations of worldwide prevalence of chronic hepatitis Bvirus infection: a systematic review of data published between 1965 and 2013. Lancet. 2015;386:1546-1555.
5. Protection against Viral Hepatitis. Recommendations of the Immunization Practices Advisory Committee (ACIP). MMWR Morb Mortal Wkly Rep. 1990;39(RR-2):1-26.

6. Ay P, Torunoglu MA, Com S, Çipil Z, Mollahaliloğlu S, Erkoç Y, Dilmen U. Trends of hepatitis B notification rates in Turkey, 1990 to 2012.

7. Van Damme P. Hepatitis B: vaccination programmes in Europe--an update. Vaccine. 2001;19:2375-2379.

8. Sağlık Bakanlığı Doğum Öncesi Yönetim Rehberi. Ankara, 2014. Available from: URL: https://sbu.saglik.gov.tr/Ekutuphane/kitaplar/ dogumonubakim.pdf

9. Altay T, Uskun E, Akcam FZ. Seroprevalence of hepatitis B surface antigen and its correlation with risk factors among new recruits in Turkey. Braz J Infect Dis. 2012;16:339-344.

10. Kuru U, Turan O, Kuru N, Saglam Z, Ceylan Y, Nurluoglu M, Agacfidan A. Prevalence of hepatitis $B$ virus infection in pregnant Turkish women and their families. Eur J Clin Microbiol Infect Dis. 1996;15:248-251.

11. Bakar RZ, Dane B. Hepatitis B seropositivity of pregnant women and the review of Turkish literature Perinatal Journal. 2016;24:8388.

12. T.C. Iç Işleri Bakanlığı Göç Idaresi Genel Müdürlüğü. Türkiye Göç Raporu 2016. Available from: URL:http://www.goc.gov.tr/files/ files/2016_yiik_goc_raporu_haziran.pdf

13. Turkish Statistical Enstitute. Available from: URL: http://www. turkstat.gov.tr/UstMenu.do?metod=temelist

14. Chen CJ, Wang LY, Yu MW. Epidemiology of hepatitis $B$ virus infection in the Asia-Pacific region. J Gastroenterol Hepatol. 2000;15 Suppl:E3-6.

15. Nayagam S, Thursz M, Sicuri E, Conteh L, Wiktor S, Low-Beer D, Hallett TB. Requirements for global elimination of hepatitis B: a modelling study. Lancet Infect Dis. 2016;16(12):1399-1408.

16. Society for Maternal-Fetal Medicine (SMFM), Dionne-Odom J, Tita AT, Silverman NS. Hepatitis B in pregnancy screening, treatment, and prevention of vertical transmission. Am J Obstet Gynecol. 2016;214:6-14.

17. Furuncuoglu $\mathrm{Y}$, Bolukbas FF, Bolukbas C, Torun P, Ozturk R. Changes in the prevalence of HBV infection in pregnant women in Turkey between 1995 and 2015: a 20-year evaluation. Postgrad Med J. 2016;92:510-3.

18. Doğan K, Güraslan H, Özel G, Aydan Z, Yașar L. Seroprevalence rates of Toxoplasma gondii, rubella, cytomegalovirus, syphilis, and hepatitis $\mathrm{B}$, seroprevalences rate in the pregnant population in Istanbul. Turkiye Parazitol Derg. 2014;38:228-233.

19. Köse Ş, Gül S, Tatar B, Temur, Göl B. HBV, HCV AND HAV seroprevalence in pregnant women admitted to Izmir Aegean Obstetrics and Gynecology Training and Research Hospital: 20102011. Turk Hij Den Biyol Derg. 2017;74: 21-28.

20. Centers for Disease Control and Prevention. Screening for Viral Hepatitis During the Domestic Medical Examination of Newly Arrived Refugees. November 26, 2018. Available from: URL: https://www.cdc.gov/immigrantrefugeehealth/pdf/refugee-viralhepatitis-guidelines-h.pdf)

21. Inci A, Yıldırım D, Seçkin KD, Gedikbaşı A. Analysis of HBsAg positivity rate before and after vaccination in Turkish and Syrian refugee pregnant women. J Infect Dev Ctries. 2017;11:815-818.

22. Nazir Abd al-Wahab Ibrahim, Taghrid Younes Ahmad, Hasan Nabil Alhouri The prevalence of Hepatitis B Surface Antigen (HBsAg) among pregnant women admitted to one public Hospital in Damascus. Syria Int J Gastroenterol Hepatol Transpl Nutr. 2017:2:7-12

23. H. Bashour, G. Muhjazi. Hepatitis B and C in the Syrian Arab Republic: A review. 2016;22:267-273. 